\title{
PERAN NUTRISI BAGI OLAHRAGAWAN
}

Oleh: Sigit Nugroho

Dosen Jurusan Pendidikan Kesehatan dan Rekreasi FIK UNY

\section{ABSTRAK}

Nutrisi merupakan salah satu faktor yang sangat berperan dalam peningkatan prestasi bagi olahragawan. Makanan merupakan sumber energi yang utama bagi manusia. Sumber energi bagi tubuh manusia sangat diperlukan dalam melakukan aktivitas khususnya olahraga. Cepat lambatnya proses pembentukan energi dalam tubuh sangat berpengaruh terhadap prestasi seorang atlit.

Penggunaan zat gizi pada metabolisme anaerobik energi didapat terutama dari karbohidrat, sedangkan pada metabolisme aerobik energi didapat terutama dari karbohidrat dan lemak. Kebutuhan zat gizi yang diperlukan harus mengandung lemak, karbohidrat, protein, vitamin mineral dan air. Tahapan pemberian zat gizi bagi olahragawan disesuaikan dengan pemberian zat gizi pada masa waktu dipusat latihan, dekat masa pertandingan, hari-hari pertandingan dan makanan sesudah pertandingan. Untuk meningkatkan prestasi olahragawan latihan harus terprogram dengan baik, dengan memperhatikan penggunaan dan tahapan pemberian zat gizi karena energi dan gizi yang tidak cukup maka nutrient energi yang diperlukan dari glikogen otot atau glukosa darah dapat menyebabkan kelelahan

MEDIKORA Vol. IV, No 1, April 2008: 103-122 
dan akibatnya dapat mempenaruhi prestasi seorang atlet.

Kata Kunci: Nutrisi, Prestasi dan Olahragawan.

Makanan sangat penting bagi makluk hidup, termasuk bagi manusia. Makanan merupakan bidang interaksi antara manusia dan lingkungannya, dari lingkunganlah makanan diperoleh. Lingkungan mempengaruhi gizi, ciri-ciri ragawi dan kesehatan. Gangguan dalam gizi mencerminkan gangguan keseimbangan dengan lingkungan. Gizi memang merupakan masalah biokultural pada manusia. Manusia memang polifag, mempunyai spektrum makanan yang luas, dan pemakan segala (omnivor), tetapi tidak segala-galanya dimakan manusia. Makanan yang kita makan sehari-hari dipecah menjadi partikel-partikel kecil di dalam saluran pencernaan untuk diabsorpsi dan ditranport ke berbagai sel-sel di dalam tubuh. Sel-sel tubuh menstranformasi ke dalam energi kimia dalam bentuk sederhana yang dapat dipergunakan segera atau bentuk lain sebagai cadangan. Tubuh manusia terdapat sejumlah sistem metabolisme energi yang dapat menyediakan energi sesuai kebutuhan ketika beristirahat atau exercise.

Makanan merupakan sumber energi yang utama bagi manusia. Sumber energi bagi tubuh manusia sangat diperlukan dalam melakukan aktivitas khususnya olahraga. 
Cepat lambatnya proses pembentukan energi dalam tubuh sangat berpengaruh terhadap prestasi seseorang. Jumlah energi yang têrbentuk tergantung berbagai faktor, antara lain: konsentrasi substrat yang menjadi bahan baku energi dan intensitas olahraga yang dilakukan. Menurut Wolinsky (1994) dengan makanan yang optimal maka energi dapat tersedia dengan cukup, sehingga menghasilkan kemampuan kerja dan waktu pemulihan yang lebih baik, kelelahan dapat diatasi secara lebih efektif karena zat gizi cadangan dapat digunakan untuk kembali pada keadaan homeostasis. Oksigen, air dan zat gizi dibutuhkan untuk proses kehidupan. Makanan seorang atlet harus memenuhi semua zat gizi yang dibutuhkan untuk mengganti zat-zat gizi dalam tubuh yang berkurang akibat aktivitas sehari-hari dan olahraga. Menu seorang atlet harus mengandung semua zat gizi yang diperlukan yaitu karbohidrat, lemak, protein, vitamin, mineral dan air. Menu atlet disusun berdasarkan jumlah kebutuhan energi dan komposisi gizi penghasil energi yang seimbang

Peranan energi dan gizi dalam olahraga penting diperhatikan, misalnya kelelahan dapat terjadi akibat tidak cukupnya ketersediaan nutrient energi yang diperlukan dari glikogen otot atau glukosa darah. Mungkin juga akibat tidak berfungsi sistem energi secara optimal akibat defisiensi

MEDIKORA Vol. IV, No 1, April 2008: 103-122 
nutrient lain seperti vitamin dan mineral. Kelebihan lemak tubuh (obese) atau berkurangnya berat badan akibat hilangnya jaringan otot akan mempengaruhi performance atlet (William, 1991). Semua aktivitas fisik memerlukan energi. Kebutuhan energi yang diperlukan bervariasi sesuai dengan derajat kegiatan/ aktivitas yang dilakukan, sebagai contoh dengan jalan kaki 18 menit/km ( santai), 10 menit $/ \mathrm{km}, 8$ menit $/ \mathrm{km}$ dan 5 menit $/ \mathrm{km}$ untuk berat badan $50 \mathrm{~kg}$ memerlukan energi masing-masing $2 \mathrm{kal} /$ menit, $5 \mathrm{kal} /$ menit, $6 \mathrm{kal} /$ menit dan $10 \mathrm{kal} /$ menit (Direktorat, 1993).

\section{PENGGUNAAN ZAT GIZI}

Pada metabolisme anaerobik aliran darah belum cukup memberikan suplai oksigen ke otot, energi didapat terutama dari karbohidrat. Suplai energi awal berasal dari proses katabolisme anaerobik adenosin trifosfat (ATP) yang terdapat di dalam otot. Terjadinya kontraksi otot akibat adanya energi yang diperoleh dari perubahan ATP menjadi ADP (ATP ADP + pelepasan energi). Energi selanjutnya diperoleh dari penguraian kreatin fosfat yang dengan cepat dapat menghasilkan ATP, namun simpanan kreatin sangat terbatas sehingga energi yang dihasilkan hanya untuk beberapa detik 
saja. Energi anaerobik terbanyak didapat dari perubahan karbohidrat menjadi asam laktat (Nutrition for Athletics, 1995). Pada metabolisme aerobik energi didapat terutama dari karbohidrat dan lemak. Energi yang berasal dari proses aerobik mula-mula berasal dari penguraian glikogen otot. Latihan berat memerlukan cadangan karbohidrat (glikogen) dan deplesi glikogen akan menuju kearah kelelahan. Karbohidrat penting untuk endurance. Atlet dengan latihan berat, memerlukan energi expenditure $2-3$ kali lebih besar dari individu yang tidak berlatih. Besar kebutuhan energi tergantung dari tiga area energi yang dikeluarkan yaitu: basal metabolisme rate + spesifik dinamik action + aktivitas fisik. Dalam latihan perlu energi seimbang yaitu jumlah energi yang masuk sama dengan besarnya jumlah energi yang dikeluarkan. Seseorang akan dapat berprestasi maksimal apabila keseimbangan zat gizi ini dapat selalu terkontrol. Dalam diet yang baik, tidak hanya pemasukan energi yang diperhitungkan, tetapi proporsi karbohidrat, lemak dan protein dalam taraf yang mencukupi merupakan hal yang pokok dan jika terjadi kekurangan atau ketidak seimbangan pada salah satu di antara ketiganya, prestasi dan kesehatan atlet menjadi tidak optimal (Yessis dan Trubo, 1993).

MEDI KORA Vol. IV, No 1, April 2008: 103-122 


\section{KEBUTUHAN ZAT GIZI}

Kebutuhan gizi harian atlet berubah-ubah, tergantung pada intensitas latihannya. Menu makanan harus mengandung karbohidrat sebanyak 60 - 70\%, lemak 20 $25 \%$ dan protein sebanyak $10-15 \%$ dari total kebutuhan energi seorang atlet (Direktorat, 1997)

\section{Karbohidrat}

Menurut William (1991) Karbohidrat adalah sumber energi dasar yang memungkinkan otot tetap bekerja. Atlet harus mengkonsumsi karbohidrat 60 - 70\% total energi. Karbohidrat dalam makanan sebagian besar dalam bentuk karbohidrat kompleks, sedangkan karbohidrat sederhana hanya sebagian kecil saja (< $10 \%)$.

Menurut Soekarman (1987) karbohidrat di bagi mencadi 3 macam yaitu: a) Monosakarida (glukosa dan fruktosa), b) Disakarida ( sukrosa dan maltosa), c) Polysakarida (tepung dan glikogen). Semua macam karbohidrat sebelum diserap akan dijadkan glukosa. Beberapa banyak karbohidrat yang dimakan tergantung dari beratnya latihan. Pada umumnya kebutuhan kalori akan dicukupi oleh makanan dengan perbandingan sebagi berikut: protein $15 \%$, lemak $30 \%$ dan karbohidrat 55\%. 


\section{Lemak}

Lemak didalam tubuh berupa triglikerida, asam lemak (fatty acid) dan kolesterol. Lemak disimpan berujud trigliserid. Lemak merupakan sumber energi yang paling efisien, semakin terlatih seseorang maka semakin banyak lemak yang dimanfaatkan sehingga glikogen lebih dihemat. Orang yang terlatih biasanya banyak menggunakan aerob karena hemoglobinya lebih banyak, kapasitas pernafasnya lebih besar. Lemak hanya bisa dimetaboliser dengan aerob karena miskin oksigen. Disel otot ada kandungan lemak tapi yg paling banyak di sel lemak letaknya dibawah kulit dan disekitar organ-organ dalam (jantung, usus). Sel lemak bisa bertambah dan menjadi besar kalau sudah terlalu besar maka kemampuan tubuh utk memenuhinya lebih banyak.

Jumlah lemak dalam makanan yang dibutuhkan seorang atlet berkisar antara 20-30\% dari total energi. Asam lemak esensial harus terdapat di dalam diet, sementara lemak jenuh harus direstriksi tidak lebih dari $10 \%$ intake energi. Lemak dalam tubuh berperan sebagai sumber energi terutama pada olahraga dengan intensitas sedang dalam waktu lama, misalnya olahraga endurance (Soekarman,1987). 


\section{Protein}

Protein tidak memiliki dampak besar terhadap energi, tetapi diet atlet harus cukup protein yang diperlukan untuk penyembuhan dan pertumbuhan otot, jika kurang akan merugikan kegiatan otot. Jumlah protein yang dianjurkan pada atlet untuk membentuk kekuatan otot dan kecepatan sebesar 1,2 - 1,7 g/kgBB/hari, untuk endurance/ketahanan dianjurkan 1,2 -1,4 g/ kg BB/hari. Pada latihan intensitas rendah protein diperlukan 1,4 - $2 \mathrm{~g} / \mathrm{kg} \mathrm{BB}$, latihan berat sebesar $2 \mathrm{~g} / \mathrm{kg}$ bb $\mathrm{BB} /$ hari. dan saat latihan intensif diperlukan 2,2 - 2,9 gr/kg BB. Beberapa penelitian menunjukkan bahwa protein hewani dan nabati harus diberikan dalam jumlah kurang lebih sama (Yessis dan Trubo, 1993).

Menurut Soekarman (1987) otot terdiri dari banyak protein maka diperlukan banyak sekali protein apabila ingin memperbesar otot. Kebutuhan protein untuk seseorang sudah cukup dengan $1 \mathrm{gr} / \mathrm{kg}$ berat badan. Jadi kalau beratnya $60 \mathrm{~kg}$ cukup dengan protein $60 \mathrm{gr}$ sehari-hainya. Untuk atlet memang dibutuhkan lebih banyak yaitu $2 \mathrm{gr} / \mathrm{kg}$ berat badan. Kalau seseorang atlet beratnya $60 \mathrm{~kg}$ dia harus mendapatkan protein 120 gr seharinya. Protein bukan merupakan bahan untuk pembuatan energi. Memang kadang-kadang terjadi 
protein digunakan untuk energi, tetapi hal ini terjadi kalau lemak dan karbohirat sudah habis.

\section{Kebutuhan vitamin dan mineral}

Vitamin dan mineral memainkan peranan penting dalam mengatur dan membantu reaksi kimia zat gizi penghasil energi, sebagai koenzim dan ko faktor. Pada keadaan defisiensi satu atau lebih dapat mengganggu kapasitas latihan. Kebutuhan vitamin terutama vitamin yang larut air (vit. B dan C) meningkat sesuai dengan meningkatnya kebutuhan energi. Penelitian menunjukkan bahwa deplesi besi tingkat moderate dihubungkan dengan berkurangnya performance latihan. Tambahan beberapa vitamin dan mineral yang penting diperhatikan dalam kaitannya dengan olahraga seperti vitamin A, B, C, D, E dan $\mathrm{K}$, mineral seperti $\mathrm{Ca}, \mathrm{Fe}, \mathrm{Na}, \mathrm{K}, \mathrm{P}, \mathrm{Mg}, \mathrm{Cu}, \mathrm{Zn}, \mathrm{Mn}, \mathrm{J}, \mathrm{Cr}$, Se dan F (Clark, 1996).

\section{Air dan Serat Makanan}

Air dalam tubuh merupakan komponen terbesar dimana proporsinya mencapai $60-70 \%$ berat badan orang dewasa. Selama pertandingan yang memerlukan ketahanan seperti maraton atau jalan cepat harus diperhatikan pengisian cadangan zat cair. Keadaan dehidrasi, gangguan keseimbangan air dan elektrolit serta pengaturan suhu tubuh

MEDIKORA Vol. IV, No 1, April 2008: 103-122 
dapat menimbulkan kelelahan dan membahayakan. Kehilangan air yang melebihi 4 - 5\% dari berat badan dapat mengganggu penampilan atlet. Dehidrasi berat secara potensial dapat menyebabkan temperatur tubuh meningkat dan mengarah ke heat stroke serta dapat berakibat fatal. Karena itu para atlet khususnya yang melakukan kegiatan endurance harus menyadari pentingnya minum cairan selama latihan maupun sesudahnya, walaupun belum terasa haus. Serat makanan penting untuk memelihara fungsi normal dari saluran cerna. Serat makanan yang tinggi bisa di dapat dari sayuran, buahan, grain dan kacang-kacangan (William, 1991).

\section{TAHAPAN PEMBERIAN ZAT GIZI UNTUK OLAHRAGAWAN}

Kebutuhan kalori dalam satu hari sangat tergantung dari jenis olahraga. Menurut Purba (2006) setiap cabang olahraga pada waktu latihan/bertanding mempunyai intensitas dan lamanya berbeda-beda. Cabang olahraga dapat dikelompokkan menjadi: olahraga ringan (menembak, golf, bowling dan panahan), olahraga sedang (atletik, bulutangkis, bola basket, dan soft ball), olahraga berat ( renang, tinju, gulat, kempo, judo, dan karate) dan olahraga berat sekali (balab sepeda jarak jauh $130 \mathrm{~km}$, angkat besi, maraton rowing). 
Kebutuhan kalori dapat dihitung berdasarkan kelompok-kelompok cabang olahraga dan dihitung berdasarkan tabel berikut ini

Tabel Kebutuhan energi BB1/24 jam menurut macam olahraga

\begin{tabular}{|l|c|c|c|c|}
\hline \multirow{2}{*}{$\begin{array}{l}\text { Jenis } \\
\text { Kelamin }\end{array}$} & \multicolumn{4}{|c|}{ Kal/Kg. Berat Badan/24 jam } \\
\cline { 2 - 5 } & $\begin{array}{l}\text { Olahraga } \\
\text { ringan }\end{array}$ & $\begin{array}{l}\text { Olahraga } \\
\text { sedang }\end{array}$ & $\begin{array}{l}\text { Olahraga } \\
\text { Berat }\end{array}$ & $\begin{array}{l}\text { Olahraga } \\
\text { Berat Sekali }\end{array}$ \\
\hline Laki-laki & 42 & 46 & 54 & 62 \\
Wanita & 36 & 40 & 47 & 55 \\
\hline
\end{tabular}

Sumber: Purba

Ada beberapa tahapan pemberian zat gizi untuk atlet, sebagai berikut: pemberian zat gizi pada masa waktu dipusat latihan, dekat masa pertandingan, hari-hari pertandingan dan makanan sesudah pertandingan (Purba, 2006)

\section{Waktu di Pusat Latihan}

Selama latihan penatalaksanaan diit sebenarnya harus disesuaikan secara individual apalagi untuk olahragawan pemegang piala dunia. Memang sering tidak mungkin dilakukan karena menghadapi serombongan olahragawan

MEDIKORA Vol. IV, No 1, April 2008: 103-122 
dari berbagai daerah dengan berbagai cita rasa dan kebiasaan makan.

Pada hari-hari laihan makan sebaknya tak kurang 3 kali sehari dengan catatan makan pagi juga harus cukup. Waktu makan biasanya disesuaikan dengan waktu latihan. Namun waktu-waktu makan yang biasa dapat dipertahankan apabila latihan tidak berturut-turut da waktu latihan memungkinkan, misalnya bila waktu latihan ilakukan hanya sekali sehari. Tetapi dengan meningkatnya frekuensi latihan menjadi 2-3 kali sehari, atau bagi olahraga yang memerlukan waktu latihan yang lama dan melelahkan sekali ( exhausting ) maka disarankan 4-6 kali makan sehari dalam porsi yang lebih kecil.

Dua jam sebelum latihan janganlah makan banyakbanyak. Pada permulaan masa latihan 0-2 bulan, dianjurkan protein cukup tinggi terutama bagi mereka yang memilih cabang olahraga yang mengharapkan perkembangan otot (muscle mass) yang banyak, mengingat seringnya olahragawan masuk pusat latihan dalam keadaan gizi yang belum memuaskan.

Minum haus cukup, jumlah cairan total kurang lebih 2 liter sehari apabila bila banyak keringattelah keluar pada hari-hari panas dan latihan yang intensif. Pada pengeluaran 
keringat banyak, bak ditambahkan garam dapur atau cairan garam elektrolit. Minum sari buah, kuah sop atau kaldu. Dalam pemberian selain cairan juga vitamin-vitamin dan mineral. Pada wanita terutama harus ditambah zat besi sehingga penggunaan sehari $20 \mathrm{mg}$. Teh manis hangat sangat efekif untuk mengurangi rasa haus. Minum harus diberikan sedikit demi sedikit, tak lebih dari 1-2 gelas tiap kali minum. Meminumnya juga harus lambat-lambat.

Contoh menu untuk serombongan olahragawan yang sudah masuk pusat latihan (dalam 1-2 bulan pertama) olahraga sedang, usia 20-39 tahun BBI rata-rata $55 \mathrm{~kg}$.

Kebutuhan energi : 55 x 46 kalori/hari $=2530$ kalori/hari

Protein : $1 / 8 \times 2530=316.3$ kalori $=79.1$ gram

Lemak $: 2 / 8 \times 2530=632.6$ kalori $=70.3$ gram

Hidrat arang : $5 / 8 \times 2530=1581$ kalori $=395.4$ gram

Kebutuhan bahan makanan sehari:

\section{Dekat Masa Pertandingan}

Bagi olahraga berat yang memerlukan waktu latihan yang lama sebaiknya diadakan persiapan sebagai berikut:

a. Seminggu sebelum pertandingan otot-otot yang akan digunakan diberi latihan yang melelahkan sekali. Makanannya hampir seluruhnya terdiri dari lemak, 
protein, (tinggi lemak dan protein). Diberikan selama 3 hari berturut-turut sehingga glycogen otot rendah sekali. Pada hari tyang keempat sampai waktu pertandingan tiba diberikan makanan tinggi hidrat arang.

b. Untuk semua macam caang olahraga berlaku 2 hari sebelum pertandingan diberikan makanan yang :

- mengandung lebih banyak hidrat arang daripada sebelumnya (tinggi hidat arang) dan rendah protein dan lemak disertai banyak istirahat

- mudah dicerna, tidak banyak serat

- tidak merangsang

- tiga jam sebelum pertandingan dapat diberikan kaldu air garam elektrolit (oralit) untuk menutupi kebutuhan garam dapur. Cairan diberikan tiap jam sekali sampai terakhir kurang lebih 1 jam sebelum pertandingan dimulai. Dilarang kopi, cola-cola atau minuman beralkohol.

Untuk golongan ini satu minggu sebelum pertandingan dilakukan maka makanannya tinggi protein dan tinggi lemak dan rendah hidrat arang tetapi yang masih dapat diterima lidah rata-rata orang Indonesia dan diberikan selama 3 hari. Kebutuhan enersi sehari: 60 x $54=3240$ Kalori/hari. 


\section{Hari-hari pertandingan}

Pada hari-hari pertandingan dimana tujuan utama adalah mencapai prestasi setinggi mungkin maka baik dalam menyusun menu diingat akan tekanan batin (emotional stress) yang mugkin dialami olahragawan pada hari pertandingan.

Olahragawan mungkin mengalami keluhan sakit perut, mual, muntah atau diare. Hidangan yang dimakan terlalu dekat dengan latihan mungkin akan sukar dicernakan karena kebingungan (anxiety) selain itu perut yang penuh dapat mengganggu penampilan fisik, maka diambil jarak 3 jam antara waktu makan dan aktu dimulainya pertandingan. Makanannyapun harus yang :

- mudah dicerna, tidakbanyak serat

- tidak merangsang

- tinggi hidrat arang

- cukup cairan minum dan mineral

- dilarang meminum kopi, cola-cola, minuman beralkohol atau mengandung zat asam arang (CO2)

Umumnya berlaku juga ketentuan-ketentuan yang sama seperti untuk masa latihan. Waktu makan harus disesuaikan dengan program pertandingan. Sebetulnya tidak ada menu khusus untuk karate, sepak bola, renang, balap

MEDIKORA Vol. IV, No 1, April 2008: 103-122 
sepeda, dan sebagainya. Tetapi ada perbedaan dalam pengaturan makan untuk olahraga dimana dilakukan kerja otot untuk waktu yang singkat (seperti misalnya sprint), dibanding dengan pertandingan yang memerlukan waktu lebih lama dalam tim atau perseorangan di mana diperlukan daya tahan yang baik. Untuk olahraga tim (sepak bola, voli, dan sebagainya) dan olahraga perorangan yang lama dilakukan antara lain: kano, maraton, mendayung, tenis dan sebagainya) secara umum berlaku ketentuan-ketentuan seperti berikut : misalnya pertandingan dilakukan sore maka

a. Pagi, sarapan ang mudah dicerna

b. Snack pagi yang mudah dicerna dan berkualitas baik

c. 2-3 jam sebelum pertandingan makan tidak boleh banyak. Tapi tiap jam diberi minuman 1 gelas + gula secukupnya, boleh ditambah sedikit makanan ringan yang tinggi H.A. (biskuit).

d. Selama pertandingan yaitu di waktu istirahat boleh diberikan minum paling banyak 1gelas tanpa es + sedikit makanan ringan.

e. Sesudah petandingan diberikan minuman 1-2 gelas yang hangat.

Sesudah mandi atau massage diberikan 1 gelas susu bergula atau minuman berprotein sesuai dengan kegemaran 
masing-masing. Satu jam setelah mandi diberi makan malam. Dekat sebelum atau di watu makan malam (tergantung rasa haus) boleh minum 1-2 gelas air biasa atau teh manis. Makan malam lengkap dengan buah-buahan. Sebelum tidur diberi susu 1 gelas dan boleh makan buah-buah lagi.

Untuk olahraga yang memerlukan waktu lama seperti pelari jark jauh, balap sepeda, maka perlu diberi makanan selama pertandingan dalam bentuk makanan ringan ang berprotein tinggi dengan minuman bergula (teh/air buah) dalam jumlah sedikit-dikit $(50 \mathrm{cc}$ ) dan gula (mengunyah dan menelan menghilangka/mengurangi rasa haus) setiap 5-6 km (25 menit).

\section{Makanan Sesudah Pertandingan}

Sesudah olahraga yang berjalan lama, maka makanan sanagat perlu untuk menganti lemak, karbohidrat, protein, vitamin mineral dan air yang berkurang. Sebaiknya langsung sesudah pertandingan olagragawan harus minum yang banyak cairan. Cairan dapat berupa cairan pada waktu bertanding ditambah atau dicampur dengan es krim yang mengandung karbohidrat, protein, dan lemak.

Minimal satu jam sesudah pertandingan baru atlet dapat makan bila memungkinkan dalam jumlah yang banyak. Bila berada dalam musim kompetisi maka perlu dipikirkan

MEDIKORA Vol. IV, No 1, April 2008: 103-122 
makanan yang dapat dengan cepat menganti cadanagan energi yang terkuras. Makanan yang dapat mengganti cadangan' energi dalam otot dan hati yang harus diutamakan menu yaitu terutama karbohidrat. Makanan yang mudah dicerna seperti es krim, pudding, nasi, telur setengah masak, susu, buah-buahan yang segar sebaiknya disediakan. Jadi jumlah sayuran dikurangi dahulu. Jumlah protein juga perlu ditingkatkan, karena perlu untuk pulih asal jaringan-jaringan yan cedera (Soekarman, 1987)

\section{KESIMPULAN}

Makanan merupakan sumber energi yang utama bagi manusia. Sumber energi bagi tubuh manusia sangat diperlukan dalam melakukan aktivitas khususnya olahraga. Cepat lambatnya proses pembentukan energi dalam tubuh sangat berpengaruh terhadap prestasi seseorang. Semua aktivitas fisik memerlukan energi, kebutuhan energi yang diperlukan bervariasi sesuai dengan derajat kegiatan/aktivitas.

Penggunaan zat gizi pada metabolisme anaerobik energi didapat terutama dari karbohidrat, sedangkan pada metabolisme aerobik energi didapat terutama dari karbohidrat dan lemak. Kebutuhan zat gizi yang diperlukan harus 
mengandung lemak, karbohidrat, protein, vitamin mineral dan air.

Tahapan pemberian zat gizi disesuaikan dengan pemberian zat gizi pada masa waktu dipusat latihan, dekat masa pertandingan, hari-hari pertandingan dan makanan sesudah pertandingan. Untuk meningkatkan prestasi olahragawan latihan harus terprogram dengan baik, dengan memperhatikan penggunaan dan tahapan pemberiana zat gizi karena energi dan gizi yang tidak cukup maka nutrient energi yang diperlukan dari glikogen otot atau glukosa darah dapat menyebabkan kelelahan dan akibatnya dapat mempenaruhi prestasi seorang atlet.

\section{DAFTAR PUSTAKA}

A. Purba. (2006). Kardiovaskuler dan Faal Olahraga. Bandung: Fakultas Kedokteran Universitas Padjadjaran.

Clark N. (1996). Petunjuk Gizi. PT Raja Grafindo Persada : Jakarta.

Direktorat Bina Gizi Masyarakat Departemen Kesehatan RI. (1997). Gizi Olahraga Untuk Prestasi. Departemen Kesehatan RI: Jakarta

MEDIKORA Vol. IV, No 1, April 2008: 103-122 
Direktorat Bina Gizi Masyarakat, Departemen Kesehatan RI. (1993). Pedoman Pengaturan Makanan Atlet. Departemen Kesehatan RI: Jakarta

International Scientific Consensus Conference on Current Issues on Nutrition in Athletics. (1995). Nutrition for Athletics: Monaco

Soekarman. (1987). Dasar Olahraga Untuk Pembina, Pelatih dan Atlet: Jakarta: Inti Idayu Press

William MH.( 1991). Nutrition for Fitness and Sport. Brown Publisher: Iowa

Wolinsky I, Hickson JF. (1994). Nutrition in Exercise and Sport. CRC Press: London

Yessis M, Trubo R. (1993). Rahasia Kebugaran Dan Pelatihan Olahraga Soviet. ITB: Bandung 